\title{
CULTURE OF TWO-CELL RABBIT EMBRYOS TO MORULAE
}

\author{
R. L. BRINSTER \\ King Ranch Laboratory of Reproductive Physiology, School of Veterinary Medicine, \\ University of Pennsylvania, Philadelphia, Pennsylvania, U.S.A.
}

(Received 8th November 1968)

\begin{abstract}
Summary. The rabbit embryo is able to develop from the two-cell stage to the morula in a medium containing an amino-nitrogen source as the only metabolizable component. This amino-nitrogen source can be bovine serum albumin, oxidized glutathione, or certain single amino acids such as glutamine, proline or alanine. Although a requirement for a nonnitrogenous energy source could not be demonstrated during this period, a beneficial effect of pyruvate and lactate was shown. The optimum concentration for pyruvate was approximately $10^{-4} \mathrm{M}$ and for lactate was 1 to $3 \times 10^{-2} \mathbf{M}$.
\end{abstract}

\section{INTRODUCTION}

The pre-implantation stages of the mouse embryo have been shown to require pyruvate, lactate, phosphoenolypyruvate or oxaloacetate for the development of the two-cell stage to the blastocyst (Brinster, 1965a). Likewise, the fertilized one-cell embryo and the oocyte of the mouse have been shown to require pyruvate or oxaloacetate in the culture medium (Biggers, Whittingham \& Donahue, 1967). That pyruvate is the energy source of choice for the first days of development in the pre-implantation mouse embryo, has been confirmed by the use of radio-active substrates in the culture medium (Brinster, 1967a, b). These studies show that pyruvate is oxidized to carbon dioxide in significantly larger quantities than is either lactate or glucose and accounts for most of the oxygen consumption of the embryo during the first 2 to 3 days of development. Recent studies on the pre-implantation stages of the rabbit embryo have shown that pyruvate is also oxidized preferentially by the embryos of this species during the first few days of development (Brinster, 1968, 1969).

The above studies suggest that pyruvate, perhaps supplemented with lactate, acts as the energy source for mouse embryos, rabbit embryos and possibly for the embryos of many other mammalian species. Most of the media used to culture pre-implantation rabbit embryos, however, have been undefined and therefore yield no information on whether pyruvate is an essential nutrient (Austin, 1961; Purshottam \& Pincus, 1961). A recent report by Daniel (1967) demonstrates a beneficial effect of pyruvate, lactate and phosphoenolypyruvate during the early pre-implantation period of the rabbit. The studies reported here were undertaken to examine the rôle of pyruvate and lactate in the 
development of the rabbit embryo in vitro during the first 2 days after ovulation. This is the period when pyruvate and lactate have been shown to be essential for the development of the mouse embryo.

\section{MATERIALS AND METHODS}

Rabbit embryos were collected from superovulated New Zealand White females weighing 6 to $7 \mathrm{lb}$. The techniques for superovulation and collection of the embryos have been previously described (Brinster, 1967a). The embryos used in these experiments were collected $24 \mathrm{hr}$ after mating, and most were in the two-cell stage of development. The embryos were washed free of all reproductive tract fluids, amino acids, protein, and possible energy sources before being placed in culture. The solution used for washing the embryos was a

TABLE 1

COMPOSITION OF KREBS-RINGER BICARBONATE FICOLL

\begin{tabular}{l|c|c}
\hline \multicolumn{1}{c|}{ Component } & $g / l$ & $m M$ \\
\hline $\mathrm{NaCl}$ & $6 \cdot 975$ & 119.32 \\
$\mathrm{KCl}$ & $0 \cdot 356$ & 4.78 \\
$\mathrm{CaCl}$ & $0 \cdot 189$ & $1 \cdot 71$ \\
$\mathrm{KH}_{2} \mathrm{PO}_{4}$ & $0 \cdot 162$ & $1 \cdot 19$ \\
$\mathrm{MgSO}_{4} .7 \mathrm{H}_{2} \mathrm{O}$ & $0 \cdot 294$ & $1 \cdot 19$ \\
$\mathrm{NaHCO}_{3}$ & $2 \cdot 106$ & $25 \cdot 07$ \\
Penicillin G & $100 \mu \mathrm{g} / \mathrm{ml}$ & - \\
Streptomycin & $50 \mu \mathrm{g} / \mathrm{ml}$ & - \\
Ficoll* & 1.000 & - \\
\multicolumn{2}{|c}{ * Ficoll is a synthetic non-metabolizable } \\
polymer of sucrose.
\end{tabular}

modified Krebs-Ringer bicarbonate solution (KRBF) and is shown in Table 1. Other media were prepared by adding to or modifying this basic solution.

After the embryos were washed free of possible energy sources, they were placed in drops of culture media containing only a single possible energy source. The culture method was that described by Brinster (1963). All of the embryos collected on a particular day were placed in a common pool, and ten embryos were taken from this common pool and placed in each experimental drop. After $48 \mathrm{hr}$ in culture, the embryos in each drop were examined and the number which had degenerated and the number which had developed into morulae were recorded. For statistical treatment of the data, the percentage of two-cell embryos which had developed into morulae in each drop was converted to an angular response before the calculations were made. This statistical transformation has been described by Biggers \& Brinster (1965).

\section{RESULTS}

The first studies were designed to determine if the rabbit embryo during the first 2 days of development required an energy source, a protein source, or 
both. The media employed and the results of three experiments are shown in Table 2. It is clear from these experiments that albumin, but not glucose, will support development of early rabbit embryos into morulae. Following these preliminary findings, a number of possible substrates were examined for their

TABLE 2

EFFEGT OF GLUCOSE AND ALBUMIN ON THE DEVELOPMENT OF TWO-GELL RABBIT EMBRYOS INTO MORULAE

\begin{tabular}{l|ccc}
\hline \multicolumn{1}{c|}{ Medium } & \multicolumn{3}{|c}{ Experiment } \\
& 1 & 2 & 3 \\
\hline $\mathrm{KRBF}$ & $10 \mathrm{D}$ & $10 \mathrm{D}$ & $10 \mathrm{D}$ \\
$\mathrm{KRBF}$ and $1 \mathrm{mg} / \mathrm{ml}$ albumin & $3 \mathrm{M}$ & $7 \mathrm{M}$ & $10 \mathrm{M}$ \\
$\mathrm{KRBF}$ and $1 \mathrm{mg} / \mathrm{ml}$ glucose & $10 \mathrm{D}$ & $10 \mathrm{D}$ & $10 \mathrm{D}$ \\
\hline
\end{tabular}

Ten two-cell embryos were present in each culture drop. D indicates degenerated, $M$ indicates morula.

TABLE 3

EFFEGT OF COMPOUNDS ADDED ALONE TO KRBF ON THE DEVELOPMENT OF TWO-CELL RABBIT EMBRYOS INTO MORULAE

\begin{tabular}{|c|c|c|c|c|}
\hline Compound & $10^{-2}$ & $\begin{array}{l}\text { Concentration } \\
10^{-3}\end{array}$ & $\begin{array}{l}(\text { Molas } \\
10^{-4}\end{array}$ & $10^{-5}$ \\
\hline \multirow[t]{2}{*}{$\begin{array}{l}\text { Pyruvate } \\
\text { Lactate } \\
\text { Glutathione }(\mathrm{Ox}) \\
\text { Glutathione (Red) } \\
\text { Alanine } \\
\text { Proline } \\
\text { Glycine } \\
\text { Glutamine } \\
\text { Cystine } \\
\text { Phenylalanine } \\
\text { Pyruvate + } \mathrm{NH}_{2} \mathrm{SO}_{4}(10 \mathrm{~mm})\end{array}$} & $\begin{array}{rl}20 & \mathrm{D} \\
20 & \mathrm{D} \\
1 \mathrm{M} \\
20 \mathrm{D} \\
6 \mathrm{M} \\
13 \mathrm{M} \\
17 \mathrm{D} \\
16 \mathrm{M} \\
- \\
16 \mathrm{D} \\
20 \mathrm{D}\end{array}$ & $\begin{array}{rl}20 & \mathrm{D} \\
20 & \mathrm{D} \\
5 \mathrm{M} \\
20 \mathrm{D} \\
20 \mathrm{D} \\
20 \mathrm{D} \\
20 \mathrm{D} \\
20 \mathrm{D} \\
20 \mathrm{D} \\
8 \mathrm{M} \\
20 \mathrm{D}\end{array}$ & $\begin{array}{l}20 \mathrm{D} \\
20 \mathrm{D} \\
12 \mathrm{M} \\
20 \mathrm{D} \\
20 \mathrm{D} \\
20 \mathrm{D} \\
20 \mathrm{D} \\
20 \mathrm{D} \\
3 \mathrm{M} \\
20 \mathrm{D} \\
20 \mathrm{D}\end{array}$ & $\begin{array}{l}20 \mathrm{D} \\
20 \mathrm{D} \\
20 \mathrm{D} \\
20 \mathrm{D} \\
20 \mathrm{D} \\
20 \mathrm{D} \\
20 \mathrm{D} \\
20 \mathrm{D} \\
20 \mathrm{D} \\
20 \mathrm{D} \\
20 \mathrm{D}\end{array}$ \\
\hline & \multicolumn{4}{|c|}{$10 \begin{array}{c}\text { Concentration }(m g / m l) \\
5\end{array}$} \\
\hline \multirow[t]{2}{*}{ Glucose } & $20 \mathrm{D}$ & $20 \mathrm{D}$ & \multicolumn{2}{|c|}{$20 \mathrm{D}$} \\
\hline & \multicolumn{3}{|c|}{ Concentration $(\mathrm{mg} / \mathrm{ml})$} & $0 \cdot 05$ \\
\hline Albumin & $19 \mathrm{M}$ & $17 \mathrm{M}$ & $20 \mathrm{D}$ & $20 \mathrm{D}$ \\
\hline
\end{tabular}

Each number is the total of two separate experiments in which ten embryos were placed in each concentration. $D$ indicates degenerated, $M$ indicates morula.

ability to support development of the rabbit embryo into a morula, and the results of these experiments are shown in Table 3. Neither pyruvate nor lactate alone allow the rabbit embryo to survive during the first 2 days of development. However, a number of amino-nitrogen sources do allow development to the morula. These include oxidized glutathione as well as certain individual amino acids. 
In order to determine if there was any effect of pyruvate or lactate on the in vitro development of the early rabbit embryo, glutathione, at a concentration below that which would support development alone, was employed in the culture medium in conjunction with pyruvate or lactate. The concentrations of pyruvate employed, and the results, are shown in Table 4. An analysis of variance of the data indicates that the effect of pyruvate on development is highly significant. The optimum concentration of pyruvate in the culture

TABLE 4

THE EFFECT OF PYRUVATE ON THE DEVELOPMENT OF TWO-CELL RABBIT EMBRYOS INTO MORULAE

\begin{tabular}{lc|cccc|c}
\hline \multicolumn{2}{c|}{ Substrate conc. (moles $l$ ) } & \multicolumn{5}{c|}{ Experiment } \\
Pyruvate & GSSG & 1 & 2 & 3 & 4 & Total \\
\hline $10^{-3}$ & $10^{-5}$ & 0 & 1 & 2 & 0 & 3 \\
$3 \times 10^{-4}$ & $10^{-5}$ & 1 & 3 & 6 & 0 & 10 \\
$10^{-4}$ & $10^{-5}$ & 0 & 8 & 7 & 2 & 17 \\
$3 \times 10^{-5}$ & $10^{-5}$ & 8 & 0 & 3 & 7 & 18 \\
$10^{-5}$ & $10^{-5}$ & 3 & 0 & 2 & 3 & 8 \\
\hline
\end{tabular}

GSSG, oxidized glutathione. An analysis of variance indicated the effect of pyruvate was significant, $0.01>P>0.001$.

TABle 5

THE EFFECT OF LAGTATE ON THE DEVELOPMENT OF 1-DAYOLD RABBIT EMBRYOS INTO MORULAE

\begin{tabular}{lc|cccc|c}
\hline \multicolumn{2}{c|}{ Substrate conc. } & \multirow{2}{*}{ (moles $l$ ) } & \multicolumn{5}{|c|}{ Experiment } \\
\multicolumn{1}{c}{ Lactate } & GSSG & 1 & 2 & 3 & 4 & Total \\
\hline $10^{-1}$ & $10^{-3}$ & 0 & 0 & 0 & 3 & 3 \\
$3 \times 10^{-2}$ & $10^{-5}$ & 8 & 1 & 4 & 6 & 19 \\
$10^{-2}$ & $10^{-5}$ & 7 & 5 & 3 & 8 & 23 \\
$3 \times 10^{-3}$ & $10^{-5}$ & 2 & 1 & 0 & 1 & 4 \\
$10^{-3}$ & $10^{-5}$ & 2 & 0 & 2 & 2 & 6 \\
$3 \times 10^{-4}$ & $10^{-5}$ & 0 & 2 & 0 & 3 & 5 \\
\hline
\end{tabular}

GSSG, oxidized glutathione. An analysis of variance indicated the effect of lactate was significant, $P<0 \cdot 001$.

medium under these experimental conditions is approximately $10^{-4} \mathrm{M}$. The concentrations of lactate employed, and the results, are shown in Table 5. The effect on development is highly significant, and the optimum concentration of lactate is between $1 \times 10^{-2}$ and $3 \times 10^{-2} \mathrm{M}$.

\section{DISCUSSION}

The culture requirements of the rabbit embryo during the first 2 days of development are somewhat different from those of the mouse embryo during the same period. The mouse embryo requires both an amino-nitrogen source and an energy source for development (Brinster, 1965a, b), whereas the rabbit 
embryo requires only an amino-nitrogen source during this period. Only after the mouse embryo has reached the eight-cell stage will it develop into a blastocyst requiring merely an amino-nitrogen source in the culture medium (Brinster \& Thomson, 1966).

The fact that the rabbit embryo does not need an exogenous energy source suggests either that amino acids can be utilized as an energy source or that the embryo contains an endogenous energy source. The possibility that such an endogenous energy source is utilized by the rabbit embryo has been suggested by Fridhandler (1959). This endogenous energy store could be in the form of glycogen since large quantities of glycogen are found in other embryos, such as the mouse embryo (Thomson \& Brinster, 1966) and the rat embryo (A. T. Gregoire, personal communication, 1968). However, in the mouse embryo, this glycogen does not appear to be available for use before blastocyst formation, and unavailability of an endogenous energy source may be the reason that the mouse embryos must rely on exogenous sources of energy during these first 2 to 3 days of development (Thomson \& Brinster, 1966).

When a variety of substrates is available, the rabbit embryo probably uses exogenous energy sources for a major part of its requirements. This is suggested by its substantial ability to oxidize pyruvate and lactate to carbon dioxide throughout the pre-implantation period (Brinster, 1969). The ability to oxidize pyruvate readily is similar to that found in the mouse embryo and suggests that, in vivo, the embryos obtain their energy during the first 2 days of development in a similar manner-that is, by the oxidation of pyruvate and perhaps lactate.

The optimum concentration of pyruvate for rabbit embryos $\left(10^{-4} \mathrm{M}\right)$ is similar to the optimum concentration found for mouse embryos $\left(5 \times 10^{-4} \mathrm{M}\right)$ and to the concentration of pyruvate $\left(2 \times 10^{-4} \mathrm{M}\right)$ found in the Fallopian tube secretions of the rabbit (Brinster, 1965c; Holmdahl \& Mastroianni, 1965). However, it is considerably lower than the concentration Daniel (1967) used in studying the effect of pyruvate on the early rabbit embryo. He used a concentration of $5 \times 10^{-3} \mathrm{M}$ and was able to show a beneficial effect on each day of the pre-implantation period.

The optimum concentration of lactate $\left(1\right.$ to $\left.3 \times 10^{-2} \mathrm{M}\right)$ found in these experiments, is about the same as the optimum concentration $\left(5.0 \times 10^{-2} \mathrm{M}\right)$ found for mouse embryos but is ten times higher than the concentration $\left(3 \times 10^{-3} \mathrm{M}\right)$ found in the Fallopian tube secretions of the rabbit (Brinster, 1965c; Holmdahl \& Mastroianni, 1965). It is also about ten times higher than the concentration used by Daniel (1967) to study the effect of lactate on the pre-implantation rabbit embryo. Even with the low concentration, Daniel did find a beneficial effect of lactate on 1- and 2-day-old rabbit embryos.

In Daniel's experiments, Ham's F-10 was the basic medium (Ham, 1963). Since F-10 contains a number of amino acids, this may account for some of the differences between the results Daniel obtained in his studies on energy sources and those reported here. One of the most important differences is that, in his culture system, embryos did not grow during the first 2 days in F-10 containing amino acids, but no glucose or pyruvate, whereas, in this study, embryos were able to grow for 2 days on some single amino acids. The confusion about the rôle of amino acids in the culture of early rabbit embryos is further accentuated by 
the finding (Daniel \& Olson, 1968) that certain single amino acids (cystine, tryptophane, phenylalanine, lysine, arginine and valine) were essential for cleavage of the early rabbit embryo. One possible reason for differences between Daniel's studies and those reported here is that different culture methods were used by the two investigators. Further work is needed to determine the exact rôle of amino acids in the development of the early rabbit embryo.

\section{ACKNOWLEDGMENTS}

The excellent technical assistance of Miss Mary Ryans is gratefully acknowledged. Financial support for this research was obtained from the National Institutes of Child Health and Human Development, HD 03071, HD 02315, and the Pennsylvania Department of Agriculture.

\section{REFERENCES}

Austin, C. R. (1961) The mammalian egg. Blackwell Scientific Publications, Oxford.

Biggers, J. D. \& BRINSTER, R. L. (1965) Biometrical problems in the study of early mammalian embryos in vitro. F. exp. Zool. 158, 39.

Biggers, J. D., Whittingham, D. G. \& Donahue, R. P. (1967) The pattern of energy metabolism in the mouse oocyte and zygote. Proc. natn. Acad. Sci. U.S.A. 58, 560.

BRINSTER, R. L. (1963) A method for in vitro cultivation of mouse ova from two-cell to blastocyst. Expl Cell Res. 32, 205.

BRINSTER, R. L. (1965a) Studies on the development of mouse embryos in vitro. II. The effect of energy source. F. exp. Zool. 158, 59.

Brinster, R. L. (1965b) Studies on the development of mouse embryos in vitro. III. The effect of fixednitrogen source. 7. exp. Zool. 158, 69.

BRINSTER, R. L. (1965c) Studies on the development of mouse embryos in vitro. IV. Interaction of energy sources. F. Reprod. Fert. 10, 227.

Brinster, R. L. (1967a) Carbon dioxide production from glucose by the preimplantation mouse embryo. Expl Cell Res. 47, 271.

BRINSTER, R. L. (1967b) Carbon dioxide production from lactate and pyruvate by the preimplantation mouse embryo. Expl Cell Res. 47, 634.

Brinster, R. L. (1968) Carbon dioxide production from glucose by the preimplantation rabbit embryo. Expl Cell Res. 51, 330.

BRINSTER, R. L. (1969) Radioactive carbon dioxide production from pyruvate and lactate by the preimplantation rabbit embryos. Expl Cell Res. 54, 205.

Brinster, R. L. \& Thomson, J. L. (1966) Development of eight-cell mouse embryos in vitro. Expl Cell Res. 52, 308.

Daniel, J. G., JR (1967) The pattern of utilization of respiratory metabolic intermediates by preimplantation rabbit embryos in vitro. Expl Cell Res. 47, 619.

Daniel, J. C., JR \& Olson, J. D. (1968) Amino acid requirements for cleavage of the rabbit ovum. $\mathcal{F}$. Reprod. Fert. 15, 453.

Fridhandeer, L. (1959) Glucose metabolism in rabbit ova, morulae, and blastocysts. Fedn Proc. Fedn Am. Socs exp. Biol. 18, 48.

Ham, R. G. (1963) An improved nutrient solution for diploid Chinese hamster and human cell lines. Expl Cell Res. 29, 515.

Holmdahl, T. H. \& Mastroianni, L., JR (1965) Continuous collection of rabbit oviduct secretions at low temperature. Feri. Steril. 16, 587.

Purshottam, N. \& Pincus, G. (1961) In vitro cultivation of mammalian eggs. Anat. Rec. 140, 51.

Thomson, J. L. \& Brinster, R. L. (1966) Glycogen content of preimplantation mouse embryos. Anat. Rec. 155, 97. 